into the 1970s. Each of the objects would be launched either in 1974 or 1975 , following on the series of more conventional satellites already arranged for the period up to 1972. The intention seems to be to select one or even two of the projects in time for the next council meeting in July.

At the same time, the management of the European space effort is likely to be further simplified. Talks have been under way for some time on the merging of a large part of ELDO and ESRO, and there should be some news of progress by July. The outcome seems to be encouraging, although nobody is clear how British attitudes towards ELDO will be reconciled with declared interests in research and applications such as the CETS television satellite.

The ESRO report for 1968, just published, captures some of the enthusiasm which is beginning to be felt again. For the first time, there is also a section called "Satellites in Operation". The sounding rocket programme, so far the mainstay of ESRO research, continued at much the same level as before, with twenty launchings last year. For the first time, however, ESRO's launching facilities at Kiruna in Sweden were used by national groups-a welcome step towards the promised role of ESRO as a provider of facilities out of the reach of individual states. The report also shows that the recommendations of the Bannier report on working methods have been taken to heart. An extension of the powers of the Director-General (Professor Hermann Bondi) is the main change, and has much to do with the sudden upsurge in ESRO's fortunes. ESRO's pessimistic attitude in offering only shortterm contracts to its A-grade staff is likely to be changed, and there is talk of some kind of career structure once the future of ESRO in the European space agency is settled.

As usual, the report has a section on the distribution of contracts among member states-almost obligatory now for a European cooperative venture in science and technology - which this year uses a weighting technique depending on the supposed technological worth of the contracts to cloud the issue further. States such as Spain and Denmark still come off significantly worse than France and Belgium. The report lists the ratio of the percentage of contracts which each state received to the percentage of the ESRO budget which it contributes. The ratio is highest for France (1.927), and least for Denmark $(0 \cdot 301)$. The ratio for Britain is $0 \cdot 650$.

Of the six spacecraft now under discussion for the next phase of the programme, two are fairly standard ionosphere and atmosphere satellites. The other projects, likely to be looked on more favourably in ESRO's present mood, are an ultraviolet astronomy satellite, a cosmic ray satellite, the Mercury probe and a geostationary satellite to study the magnetosphere. The Mercury probe is the subject of a design study by Messerschmitt-Bölkow, and would have to be undertaken as a joint effort with NASA. As well as the television cameras, the payload includes a Mariner-like complement of photometers, polarimeters and radiometers to study the surface and atmosphere of the planet, as well as magnetometers and micrometeorite detectors to investigate the interplanetary medium up to 0.4 astronomical units from the Sun. So far, American and Russian planetary probes have reached only the adjacent planets Mars and Venus.

\section{NUCLEAR POWER}

\section{Club for the Well-10-do}

Атомг energy has done little for the developing countries so far. Less than two per cent of all atomic power stations either built or being built lie outside the charmed circle of advanced industrial nations. The chief reason for this is that at present nuclear power is only competitive with oil, coal and water when produced in plants too big for most developing countries. But other and cheaper nuclear techniques are not making the contribution that they might to developing economics, and the International Atomic Energy Agency has just issued a booklet lamenting the situation (Atomic Energy in the Developing Countries, IAEA, Vienna, 1969).

The IAEA's regular budget is \$11 million for 1969 , and the agency is hoping for a further $\$ 2$ million in voluntary contributions from its member states. Voluntary contributions do not always turn up, however, and the IAEA managed to earn only $\$ 1 \cdot 3$ million in this way in 1968. The funds avajlable to the agency's own technical assistance programme have been shrinking, both in real terms and in relation to demand, for several years; in the early days, nearly every reasonable request for technical assistance could be met, but now the proportion is one in four.

This is why the IAEA is having to concentrate on inexpensive pioneering projects, hoping to seed the ground in preparation for larger ventures financed by the UN Development Programme. The fastest growing sector of the agency's activities has recently been the use of isotopes in agriculture. A plant breeding programme was set up jointly with the FAO in 1964 , and the scientists engaged in this programme have obtained valuable mutants of rice and wheat by gamma irradiation. One rice strain has a doubled protein content, while two mutant strains of wheat have just been released to farmers in Italy after four years of FAO-IAEA trials. Isotopes are also finding a use in studies of fertilizer use, insect control, food preservation and the tracing of insecticide residues.

But IAEA is well aware that in the long term the greatest impact of nuclear science will be its provision of cheap and limitless electric power. The agency has sent advisory missions to Brazil, Greece, Kuwait, Korea and Yugoslavia to help plan nuclear power programmes. Other countries have been helped in framing legislation on nuclear safety. Argentina and India are now committed to nuclear programmes, while Brazil and Greece will probably take their first steps soon. Cheap power will make large desalination plants possible, and the planning of a joint Mexico-United States-IAEA plant, capable of producing 1,000 million gallons of fresh water a day, is partly complete.

\section{CONCORDE \\ The Sky is not the limit}

The British and French Governments have at last come clean and admitted that the estimated cost of Concorde has increased by more than 50 per cent since 1966. Mr A. Wedgwood Benn, the Minister of Technology, announced at question time in the House of Commons on May 21 that the current estimate, agreed 
by both governments, is $£ 730$ million, compared with the estimate of $£ 450$ million in 1966 . The fact that both partners have agreed on the estimate and on its publication clearly indicates that they are determined to go on with the project in the face of escalating costs, and the statement should, for the time being at least, put an end to speculation about the cost of the programme and the possibility of its cancellation. Mr Benn also said, however, that the basic estimate of $£ 730$ million does not include any contingency allowance for major unforeseen difficulties. All that he would say at present about the flight tests was the lukewarm comment that they had been encouraging. But further design changes involving anything more than a 15 per cent increase in the estimates would, he said, indicate a fundamental redesign of the aircraft. Mr Benn avoided saying categorically that Britain would withdraw from the project if such a fundamental redesign becomes necessary but that is obviously the implica. tion. Fifteen per cent more than $£ 730$ million seems to be the ceiling for Concorde as far as the British Government is concerned. What the French Government thinks will not be known until Mr Benn has talked to his counterpart after the French presidential elections.

The amount of money spent so far and the breakdown of the additional costs is instructive. To date Britain has spent $£ 170$ million and France $£ 160$ million; to complete the programme Britain will have to spend another $£ 170$ million and France $£ 230$ million. Devaluation and pay and price increases in both Britain and France account for $£ 130$ million of the additional costs. Of the remaining $£ 150$ million, $£ 20$ million is attributed to increases in overheads at the contractors and about $£ 85$ million to design changes involving meeting new criteria of airworthiness, maintaining payload and range performance, strengthening the undercarriage and improving the performance of various items of equipment. The remainder of the extra cost is apparently the result of initial underestimates of the time and effort that would be needed to complete the programme.

$\mathrm{Mr}$ Benn's dilemma is obvious. Having gone so far, and gained at least the illusion of a lead over the United States, the British and French governments would find cancellation a bitter pill. But Concorde remains an unknown quantity. Will it fly well when the supersonic region is reached ? Will its range justify the sales talk? What, in any case, will be the reaction of the public authorities which must make legitimately decisions about supersonic bangs? In these circumstances, it is sensible to set an arbitrary limit. Both governments must be wishing they had gone for an air bus or a jumbo jet.

\section{GARBAGE DISPOSAL \\ Electricily from the Dustbin}

Pranos and old bedsteads are not the most promising fuels for generating electricity, but the Greater London Council's Edmonton Refuse Incineration Plant is being built with feed chutes large enough to take a grand piano. In the plant, the first large scale total incineration plant to be used for continuous generation of electricity in Britain (although similar plants are working in Europe), the hot furnace gases of refuse incinerators will be used to drive four conventional 12.5 MW steam turbo-generators. Furnace tempera- tures of up to $1,800^{\circ} \mathrm{F}$ are necessary in continuous total incineration plants but the electrostatic precipitators which remove particulate pollution before the gases are discharged work at about $600^{\circ} \mathrm{F}$. If the plants are large enough, this high grade heat can be used to make them economically viable as well as sociably desirable by linking the incinerators to electricity generators, neighbourhood heating or process heating systems. At a meeting of the Institution of Mechanical Engineers recently, Mr P. D. Pepé and Mr G. M. Turner explained that the GLC, in cooperation with the Eastern Electricity Board, has selected power generation as the only feasible scheme at Edmonton, and, making the most of their assets, they are to use sewage effluent from the GLC's Deepham sewage works for cooling plant.

According to the GLC's costing studies, the capital costs of the power generation scheme $(£ 10,420,000)$ are considerably higher than the costs of a nonrecuperative scheme $(£ 7,640,000)$, which wastes the available heat, but the average return on the capital for the generating plant is 11.2 per cent. In other words, the power generation plant costs $12 s 10 d$ less for every ton of rubbish handled, which makes a saving of $£ 312,500$ a year.

When operating at full capacity the plant will automatically handle 1,333 tons of crude refuse a day, generating between 25 and $35 \mathrm{MW}$ of electricity. Peak consumption will be 1,667 tons a day giving a peak generation of $45 \mathrm{MW}$. The refuse will be burnt to an inert residue only one tenth the volume of the unsorted refuse, and metals - which by 1970 will be $7 \cdot 2$ per cent by weight of the crude refuse and 8.5 per cent by 1980 - are to be salvaged.

Household refuse is, of course, an extremely variable fuel, but the long term trend is definitely on the side of the GLC and the Eastern Electricity Board. At the same meeting $\mathrm{Mr} \mathrm{R}$. H. Watson said that in Britain, as gas and electricity replace solid fuel for domestic heating, the calorific values of rubbish are rising chiefly because of increasing proportions of paper and

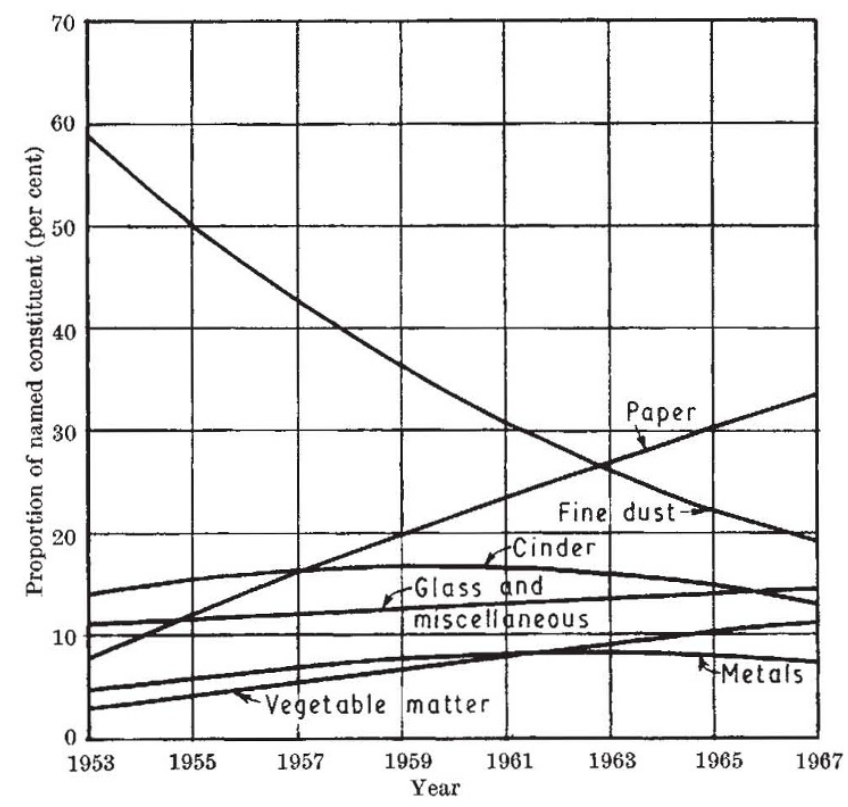

Variation in the composition of refuse from a British city with a population of about 500,000 (by courtesy of the Institution of Mechanical Engineers). 